FACTA UNIVERSITATIS

Series: Law and Politics Vol. 15, N 2, 2017, pp. 145 - 155

DOI: 10.22190/FULP1702145T

Original Scientific Article

\title{
LEGAL AND ETHICAL JUSTIFICATION OF COMPENSATION REGARDING COMPULSORY VACCINATION INJURIES ${ }^{1}$
}

\author{
UDC 614.47:608 \\ 347.5:614.47
}

\begin{abstract}
Ivana Tucak
Faculty of Law Osijek, Josip Juraj Strossmayer University of Osijek, Croatia

Abstract. Although vaccination as a modern public health measure has been accompanied with controversies since its very beginning, today medicine has no doubts with respect to its benefits for individuals and whole communities. It is to be noted that vaccination has significantly decreased the incidence and mortality rate of a number of infectious diseases. When propagating vaccination, scientists point not only to its effectiveness but also to its efficiency. It is believed that preventive national mass vaccination programmes have saved billions of euros considering treatment and other medical costs which would be incurred due to the outbreak of a disease. Vaccination and other medications may imply certain unwanted reactions. Although severe side effects of vaccination are rare, in such cases compensation of injuries bears great relevance for the success of immunization policies and maintenance of the public trust. This paper attempts to clarify why traditional tort litigation is not convenient in this view. The injured parties often face long-lasting judicial proceedings with an uncertain outcome. What is even worse is that such cases often concern children who are likely to need lifelong care. On the other hand, vaccine manufacturers are also vulnerable. Vaccine production is expensive and subject to strict supervision. High costs cases are particularly discouraging for manufacturers, which jeopardizes public health goals. Our aim is to demonstrate that the Republic of Croatia should introduce the so-called "no-fault" compensation programme which would bind the state to compensate for the damage done to its citizens in the name of the principles such as solidarity and justice.
\end{abstract}

Key words: solidarity, justice, equality, vaccines, compensation, liability

\footnotetext{
Received May $24^{\text {th }}, 2016$ / Accepted June $7^{\text {th }}, 2017$

Corresponding author: Ivana Tucak

Faculty of Law Osijek, Josip Juraj Strossmayer University of Osijek, S. Radica 13, 31000 Osijek, Croatia

E-mail: itucak@pravos.hr

${ }^{1}$ This paper has been previously published as: Ivana Tucak, "Legal and Ethical Justification of Compensation Regarding Compulsory Vaccination Injuries" in Urban Bacher et al. (eds.), Interdisciplinary Management Research XII, Josip Juraj Strossmayer University of Osijek, Faculty of Economics in Osijek, Osijek, 2016, ISSN 1847-0408, pp. 783-800.
} 


\section{INTRODUCTION}

Although vaccination as a modern public health measure has been accompanied with controversies since its very beginning, today biomedicine has no doubts with respect to its benefits for individuals and whole communities. It is assumed that vaccination has significantly curtailed the infectious disease occurrence and mortality rates (Looker \& Keelan; $2011,1)$. When propagating vaccination, scientists point not only to its effectiveness but also to its cost-reducing effect. It is believed that preventive national mass vaccination programmes have saved billions of euros considering treatment and other medical costs which would be incurred due to the outbreak of a disease (Parmet; 2005, 73; Hodge \& Gostin; 2001-2001; 876; Beauchamp \& Childress; 2001, 251).

Like other medications, vaccination may also imply certain unwanted reactions. Although severe side effects of vaccination are rare, in such cases compensation of injuries bears great relevance. This paper attempts to clarify why traditional tort litigation is not convenient in this view. The injured parties often face long-lasting judicial proceedings with an uncertain outcome. What is even worse is that such cases often concern children who are likely to need lifelong care. On the other hand, vaccine manufacturers are also vulnerable. Vaccine production is expensive and subject to strict supervision. Unlike medications treating chronic diseases which have been used for decades, vaccines are administered only several times during a lifetime (Parmet; 2005, 88). High costs cases are particularly discouraging for manufacturers, which ultimately jeopardizes public health goals.

Our aim is to demonstrate why the Republic of Croatia should introduce a vaccine compensation programme which would bind the state to compensate for the damage done to its citizens in the name of the principles such as solidarity, equality and justice (Asveld; 2008, 251; Beauchamp \& Childress; 2001). The number of such programmes is growing all around the world and Croatia should be particularly sensitive to this issue since vaccination of children against statutory specified diseases is compulsory.

This paper is aimed at precise determination of principles which should set grounds for political and legal decisions on the "acceptability of technological risks" (Asveld; 2008, 251). Most authors acknowledge their importance both in medical and public health ethics (Faden et al.; 2003, 1547). Still, what remains controversial is how to find the right balance between these principles. In terms of compulsory vaccination, one should seek ways how to establish a balance between the autonomy of an individual and the benefits of the whole community from "an efficient vaccination programme" (Faden et al.; 2003, 1547). The key element in this context is to identify the principles which should lay foundations for compensation for vaccine injuries (Mello; 2008, 32).

The paper is divided into five sections. The second section refers to the legitimacy of the use of compulsion in vaccination programmes. Challenging the additional requirements which need to be met to make the use of compulsion compliant with contemporary perceptions, the third section further elaborates the topic raised in the second section. The other sections of the paper examine the foundations for introduction of government- funded compensation programmes. The fourth section focuses on the utilitarian arguments supporting introduction of such programmes. The fifth one sheds light on some values, such as justice, solidarity and reasonableness, which should constitute a basis for these arguments and the sixth one explores the practice of the states which have already adopted the above programmes.

Although this paper primarily concentrates on compulsory vaccination of children, the conclusions may comprise other compulsory vaccination programmes, in particular the 
programmes of vaccination against smallpox due to the threat of bioterrorist attacks and work related vaccination which refers to, above all, healthcare workers. This paper does not deal with the specificities relating to compensation for the damage resulting from voluntary vaccination (See Mello; 2008, 41-42).

\section{COERCION AND VACCINATION}

The respect for the autonomy of an individual regarding his/her choice of medical treatment is today deemed as one of the fundamental values of both "medical and public health ethics" which formulates it as the concept of informed consent (Faden et al.; 2003, 1547-1548). Informed consent is primarily perceived as the obligation of medical staff to provide patients with adequate information on a medical intervention and the risks connected therewith as well as with available alternatives, but today it also implies undertaking necessary steps to make this information comprehensible to patients and enable them to make a reasonable decision (Faden et al.; 2003, 1548; Beauchamp \& Childress; 2001, 77).

Although nowadays many states are known for their successful voluntary childhood immunization policies, such as the UK where vaccination is only recommended "for good of society" (Henson; 2007-2008, 61), a fair number of states, like the Republic of Croatia, qualify childhood immunization as an obligation. Such interference with the autonomy of an individual, in this case that of parents, is depicted as "ethically problematic" and requires strong justification in liberal democracies (Malmquist et al.; 2011, 22). Although the arguments for compulsory vaccination, which are based on paternalistic concerns or personal benefits, are still deemed acceptable, the arguments for protection of other people from harm are much stronger (Malmquist et al.; 2011, 21).

The introduction of programmes of vaccination against highly infectious diseases is aimed at achieving the so-called herd immunity, i.e. high immunization coverage, which with respect to most diseases means $90 \%$ of a population. This is supposed to prevent circulation of infectious agents within a community (Field \& Caplan; 2008, 115, 122). The accomplishment of this goal entails "a hierarchy of public goods" in which health is preferred over the rights of individuals to freely decide on the medical intervention which they need to undergo (Field \& Caplan; 2008, 115).

The introduction of vaccination is thus justified with "self-regarding" and "otherregarding" concerns. Such justification is not vaccination-specific since it is also applied in clinical research involving human subjects (Faden at al.; 2003, 1549). In regard to some infectious diseases, the protection of personal interest prevails over the rights of a community. This is particularly evident when it comes to vaccination of a person due to his/her travel to countries where particular infectious diseases are endemic. Still, it should be noted that the protection of third parties is less prominent when imposing compulsion for the purpose of vaccination against sexually transmitted diseases such as HPV (human papillomavirus). This is a disease which can be transmitted exclusively through sexual contact, so the number of infected persons is much smaller and such are the appertaining risks (Mello; 2008, 38; Malmquist et al.; 2011:22).

Although public health law allows the government to introduce coercion for the sake of promotion of public health values and hence to restrain individual freedoms and impose the positive obligation of immunization, the limits of these state powers needs to be defined 
though. Today this is particularly important due to the vociferous critiques that the use of coercion in immunizations programmes "reinforces a culture of coercion" (Shapiro; 2012, 155) and that vaccines should be administered on a voluntary basis. However, the division into voluntary and compulsory vaccination programmes can seem to be too simple (Faden et al.; 2003, 1548). Even though both kinds of programmes are mandatory, there is a huge "moral difference" between forcing people to get vaccinated and fines imposed on individuals. Can the state use "actual force" to achieve satisfying immunization coverage (Shapiro; 2012, 116)?

The use of coercion by the state in preventing the spread of infectious diseases is not a new idea (Flanigan; 2014, 13). Long before the introduction of compulsory vaccination, states had quarantined individuals at risk of getting infected or infected people for the purpose of preventing the spread of diseases. From the viewpoint of Flanigan, the quarantine costs are for an individual much higher than the vaccination costs since quarantine implies restriction of freedom of movement and social isolation. The use of quarantine is justified by the fact that the danger of quarantined people is usually greater than the danger of people subject to vaccination. Flanigan completes the comparison of these two measures with the assertion that personal costs and benefits are of the same kind, but they differentiate from each other by their intensity.

Nowadays, thinks Shapiro, due to the values attributed to the protection of bodily integrity, a person cannot be controlled and locked in "a wrestling hold" while he/she is being administered a vaccine, though the procedure results in nothing but a pinprick (Shapiro; 2012, 116). The only thing permitted in this view is providing strong incentives (Shapiro; 2012, 116; Hodge \& Gostin; 2001-2002, 835). The measures undertaken against those who avoid vaccination include: loss of education possibilities, social isolation, loss of custodial (parental) rights, civil fines and only sometimes, criminal penalties (Shapiro; 2012, 138; Hodge \& Gostin; 2001-2002, 833). Regardless of the legitimacy of coercion, its use should be reduced as much as possible while assuring measures for the promotion of fairness among affected individuals, which is the topic of the next section (Flanigan; 2014, 20; Mello; 2008, 36).

\section{ETHICAL JUSTIFICATION OF COMPULSORY VACCINATION}

The previous section has revealed that imposing the obligation of vaccination on a person is morally and legally acceptable due to the benefits for the whole community. Yet, authors stress that full ethical justification of mass vaccination could be possible only if the additional conditions are fulfilled (Faden at al.; 2003, 1549; Mello; 2008, 36). These additional conditions shall provide fairness to the individuals who are subject to a compulsion regime (Mello; 2008, 36). This section takes into consideration some of the conditions which, in our opinion, necessarily need to be fulfilled in this context and which are broadly present in relevant discussions. First of all, the system of vaccination distribution shall itself be fair (Faden at al.; 2003, 1549). Law and bioethics see numerous discussions on the conflict between the state and an individual considering "the allocation of health care resources“ (Gilbar \& Bar-Mor.; 2008, 225). Healthcare appears here as an example of "a scarce resource". Fairness in the access to healthcare will be achieved if all the community members have "an equitable means of access". It means that the access must not be restricted to those who have sufficient financial resources to afford it (Field \& 
Caplan; 2008, 115). The justice in the context of vaccination implies an access of all the children to "safe" and "effective" vaccines (De Castro Lessa \& Garoffe Dorea; 2013, 230).

Malmquist points out that the vaccination costs and its benefits should be equally distributed in accordance with Rawls' postulate from his A Theory of Justice and in a way which best satisfies the interest of the most endangered ones. In order to accomplish this goal, publicly-funded vaccination programmes should be preferred over "consumer-based" or "partially subsidised approaches" (Malmquist et al.; 2011, 23).

Second of all, it is important that states implementing compulsory vaccination programmes assure "due process" before a person is deprived of freedom of choice (Mello; 2008, 36). Possible problems relating to this issue can be found in the practice of the Hungarian Constitutional Court. In the Republic of Hungary, the Constitutional Court has invalidated the provision ("the second sentence in Section 58 para. (4) of Act CLIV of 1997 on Healthcare") permitting the health authorities to order vaccination "without delay" of a person who has refused to get vaccinated. In its decision, the Constitutional Court has recognized the importance of vaccination of individuals but also established that the existing solution leads to violation of the right to "a legal remedy, personal self-determination and bodily integrity" (The June 2007 Decision of the Hungarian Constitutional Court, case No 39/2007; See also Sadurski; 2014, 282).

The third ethically required condition, which is in the spotlight below, refers to the need for introduction of a financial compensation programme intended for those who have been harmed by vaccination or for their families (Mello; 2008, 36; Faden et al.; 2003, 1549). This measure should provide an additional guarantee that the use of coercion against individuals with respect to vaccination will be restrictive (Mello; 2008, 36).

\section{UTILITARIAN ARGUMENTS FOR INTRODUCTION OF COMPENSATION PROGRAMMES}

Even though it can often be heard that vaccines are safe, they are still "biologically active agents" which may, though rarely, do harm to individuals. (Wilson \& Keelan; 2012, 122). Even a properly manufactured and administrated vaccine may bring to injuries and death (Henson; 2007-2008, 62). Adverse effects are to appear with statistical certainty and the most affected ones are members of the most vulnerable groups such as children and old people (Mello; 2008, 37). Most consequences of vaccination are mild and include local reactions and a slightly elevated body temperature, but some people might suffer fatal or severe consequences of vaccination (Faden et al.; 2003, 1549).

In the year 2012, Croatia registered "39 adverse events which were classified as severe in a broader sense (e.g. an extensive local reaction - larger than $5 \mathrm{~cm}$ in diameter, post-vaccinal measles and rubella are all classified as severe adverse events). There were five lifethreatening (e.g. anaphylaxis) or hospitalization-requiring reactions (e.g. convulsions, neuritis)“ (The Official Website of the Croatian National Institute of Public Health, http://www.hzjz.hr/wp-content/uploads/2013/11/pitanja-za-web.pdf).

These adverse events entail medical and other costs which represent a great burden for an injured person (Wilson \& Keelen; 2012, 122). The compensation should result in "restitution in the amount of past and expected future economic losses" accompanied with an amount for "the injured person's pain and sufferings" (Mello; 2008, 33). Indeed, it is beyond any doubt that some are going to suffer huge damage and no one knows who it will be. Mello highlights that people are hidden behind Rawls" "veil of ignorance“" (Mello; 2008, 41). 
The practical reasons why states have opted for introduction of publicly-funded programmes for vaccination damage compensation are often reflections of political and economic concerns. These are, above all, utilitarian reasons which should facilitate the readiness of an individual to get vaccinated and the willingness of manufacturers to proceed with vaccine production and invest into its further improvements (Wilson \& Keelan; 2012, 123; Mello; 2008, 33).

It is quite sure that a traditional tort system does not seem to be an appropriate solution for compensation for the damages emerging in this field. For a person having suffered vaccination injuries, litigation management can be an expensive and uncertain thing and many claimants will not get proper compensation (Parmet; 2005, 90). On the occasion of implementing mass immunization programmes in the United States, whereat doctors acted as "learned intermediaries", individuals were entitled to file a lawsuit against the manufacturer. Based on "the product liability", the manufacturers would face consequences if a vaccine was "defectively designed or manufactured" or if there was no warning about the appertaining risks (Mello; 2008, 33; Looker \& Keelan; 2011, 4). The manufacturers were not happy with such a situation, the vaccine prices went up due to high court proceedings costs and there was a danger to the sustainability of vaccine supply (Parmet; 2005, 88; Mello; 2008: 36). It was the primary motivation for introduction of the National Vaccine Injury Compensation Program (VICP) in the USA (Wilson \& Keelan; 2011, 123).

Vaccine manufacturers are exceptionally vulnerable to tort litigation costs (Parmet; 2005, 88). Individuals get vaccinated only several times during a lifetime and therefore vaccine manufacturers are not in the same position as medicine manufacturers who have been combatting chronic diseases with medications for decades. It should be mentioned that, emphasizes Parmet, governments are the main vaccine buyer, so they have a powerful effect on shaping the vaccine prices. Besides, in terms of vaccines against rare or eradicated diseases, which are the main target of bioterrorists, their development depends only on governmental funds (Parmet; 2005, 88).

What is imposed here is the issue of the power of these utilitarian arguments with respect to the above goals. Utilitarianism applies "an explicit balancing of relevant factors to determine the optimum result for the greatest number of people regardless of competing individual needs“ (Field \& Caplan; 2008, 134). In line with these arguments, social benefits from such programmes should exceed the compensation costs (Mello; 2008, 34).

Parmet supports the thesis that special compensation schemes aimed at reducing the risk of vaccination injuries boosts the willingness to get vaccinated. As an obvious example of a failure of an immunization programme which was not accompanied with possible compensation is the 2003 programme of vaccination of "the first responders" and other "emergency personnel" against smallpox, which was launched by former US president George Bush. Although smallpox has been qualified as an eradicated disease by the World Health Organization, vaccination against this disease was brought to the centre of attention after 11 September 2001 due to the fear of bioterrorism. Out of a total of 500,000 "civilian health care workers" who were supposed to get vaccinated, only 39,353 people actually received the vaccine. Unlike the military vaccination, which was mandatory, the vaccination of other target groups was voluntary (Parmet; 2005, 90). The fact that the consequences of the vaccine against smallpox are more troublesome than those of other widely-used vaccines was probably a relevant factor in this view. Out of a million vaccine administration cases, one can expect 1-2 deaths, 14-52 "life-threatening reactions" and 1000 "serious but not lifethreatening reactions" (Faden et al.; 2003, 1547). 
According to Parmet, education of a population about infectious disease hazards together with appertaining compensation schemes promotes the public trust and reduces the possibility of injury appearance. The efficacy of a vaccine does not depend on the existence of the trust of the vaccinated person, but trust can be of key importance for the patient's willingness to get vaccinated or to have his/her child vaccinated (Parmet; 2005, 97).

On the other hand, some authors claim that there is not enough empirical evidence supporting the argument that compensation programmes enhance or weaken a person's willingness to get vaccinated. Mello suggests that the utilitarian reasons are not strong enough and accentuates that a person's willingness to get vaccinated is mostly bound to the real risks of disease occurrence, which is, with respect to most diseases, pretty low (Mello; 2008, 35).

The widely present concern for the costs of such programmes should not be forgotten. The reasons why states hesitate to introduce them are greatly attached to the cost-related fears. What is also controversial is their priority with respect to other needs related to the immunization policy. The bare existence of such programmes appears to be an additional argument of the rather vociferous opponents of vaccination and may provide them with legitimacy in their assertions. For instance, an American programme faced harsh criticism resulting from the allegations about the link between the vaccination and autism (Wilson \& Keelan; 2012, 122-124). However, Wilson and Keelan have drawn the conclusion that these concerns have turned out to be ill-founded in many states and that the programme costs are "manageable" and "predictive". In the United States, the costs were lower-than-expected, which brought to "a large surplus of revenues" realized by the "excise tax on vaccines" (Wilson \& Keelan; 2012, 124). The compensation scheme in the United States is financed through a vaccine tax amounting to 0.75 dollars per dose (Mello; 2008, 36, 41).

\section{VALUES Which Set GROUNDS FOR COMPENSATION PROGRAMMES}

The purpose of compensation programmes should not be tailored according to costrelated issues but it should be primarily viewed from the ethical perspective (Wilson \& Keelan; 2012, 124). The main goal of such programmes should refer to meeting the solidarity, justice, fairness and reasonableness requirements. Therefore, this section offers a short overview of these values. This is particularly important due to the impossibility of standard ethical justification which is to be applied when individuals are exposed to a risk for the sake of a public good and which is based on their voluntary consent (Faden et al.; 2003, 1549). A mandatory immunization policy does not include such consent.

Justice requires "fair, equitable, and appropriate distribution" of "benefits", "burdens" and "costs" (Beauchamp \& Childress; 2001, 226). The relevant literature contains critiques of the conduct of individuals who do not have their children vaccinated in order to avoid harmful consequences of vaccination and thus enjoy the benefits from the vaccination of others and generation of herd immunity which prevents circulation of infectious agents in the environment (Asveld; 2008, 247). Their attitude is deemed unethical and contrary to one of the fundamental values in modern societies - "the value of equality". In Western civilization, the value of equality is highly appreciated and conduct implying enjoyment of benefits without bearing the burden is considered unacceptable (Asveld; 2008, 247). Such an attitude towards an immunization policy is denoted as "self-defeating" since if it was practised by everyone, the immunization policy would become unsuccessful and would not 
provide anyone with protection. (Asveld; 2008, 253) In case a community does not compensate for the damage done to individuals on account of vaccination, members of such a community will become free riders who enjoy the benefits of the immunization at the expense of those who have been injured by the vaccine (Mello; 2008, 39).

Solidarity is often perceived as the primary reason for introduction of compensation programmes (Mello; 2008, 39). What solidarity and justice have in common is putting an emphasis on the need to equally bear the respective burden on the occasion of generating a public good (Mello; 2008, 39). Every member of a community should equally bear risks and burdens. If risks are connected with the realization of a public goods, individuals who have suffered damage must not be on their own (Mello; 2008, 39). Solidarity means that we are all in this together and the burden shall not be carried only by "the losers in the vaccine lottery" (Faden et al.; 2003, 1550).

As one of the crucial values in this context, Mello singles out "reasonableness" which entails a mixture of utilitarian and deontological concerns, under the condition that it can be "efficiently" assured, "a rational vaccinees would prefer a world in which such a compensation scheme" exists (Mello; 2008, 41).

\section{VACCINE INJURY COMPENSATION PROGRAMMES}

Pursuant to Wilson and Keelan, 19 countries had introduced vaccine compensation schemes, out of which 13 are situated on the European continent. Furthermore, this mechanism is applied by three of our neighbouring countries - Italy, Slovenia and Hungary (data are for 2011. See Looker \& Keelan; 2011, 2-3). Many European countries have embraced "a vaccine liability as part of a more comprehensive no fault approach to medical accidents". This is a result of the aspiration to harmonization of healthcare policies within the EU as part of "the pan-European compensation scheme for injuries caused by defective products“ (Looker \& Keelan; 2011, 3),

As stated above, in 1986, the US Congress established a VICP enabling "no-fault administrative compensation for adverse effects" which have been scientifically confirmed as vaccine-related. The programme was initiated as a response to the childhood vaccine supply crises emerged due to the high "tort liability costs" which the manufacturers were facing. The programme was gradually extended to adult vaccination against smallpox and trivalent influenza (Mello; 2008, 33). According to a report of the US Department of Justice (2003): the VICP had managed to assure a "less adversarial", "less expensive" and "less time consuming system of recovery“ (Mello; 2008, 33).

In Italy and Slovenia, the constitutional courts played a major role in the vaccination policy. They limited the discretionary power of the legislator relating to vaccination. Precisely, the Italian Constitutional Court attempted, in a number of its decisions made in the 1990s, to set a balance between the personal right to autonomy and the universal interest for protection against infectious diseases. The Court backed the power of the legislator to impose mandatory vaccination, but it also ruled that the injured person shall have the right to compensation provided by the community. It entrusted the specification of the compensation amount and conditions to the Parliament. The Parliament remained in charge of determining the constitutionally acceptable minimum compensation. Nevertheless, this amount was subject to supervision of the Constitutional Court. In terms of restraining the powers of the legislator considering the costs and budget ("rights that have a price"), the 
Italian Constitutional Court has already shown its determination. For instance, in 1988, it declared the law relating to unemployment benefit unconstitutional since it found the subsidy amount inadequate for living (Zagrebelsky; 2003, 645).

In 2003, the Slovenian Constitutional Court held that the Infectious Diseases Act did not properly regulate the state liability for vaccination injuries. In compliance with the former Slovenian judicial practice, the state or "socio-political community", which is in charge of establishing an immunization policy, was, according to general regulations, liable for the damage which an individual could suffer as a result of vaccination, but the Slovenian Constitutional Court found that solution inconvenient and required enhancement of the protection of an individual against damage (The February 2004 Decision of the Constitutional Court of the Republic of Slovenia, Decision No. U-I-127/01, B - III 27).

The Act on the Protection of the Population against Communicable Diseases (Official Gazette 79/07, 113/08, 43/09 and 22/14-RUSRH) and the Ordinance on the Manner of Carrying Out Immunization, Seroprophylaxis and Chemoprophylaxis against Communicable Diseases, and on the Persons Subject to This Obligation (Official Gazette 103/13) represent the legal foundation of compulsory vaccination in the Republic of Croatia. Immunization programmes are enacted by the minister of health following a proposal of the Croatian National Institute of Public Health. The state is liable for providing damage compensation to persons with long-term medical conditions as a consequence of vaccination carried out in compliance with the National Immunization Programme (This information is available to the public. See The Official Website of the Croatian National Institute of Public Health, http://www.hzjz.hr/wp-content/uploads/2013

/11/pitanja-za-web.pdf ).

Although there is no special compensation programme, the state is nevertheless liable for the damage done to an individual on the occasion of vaccination. This kind of a system is being abandoned on the European continent and replaced by special compensation programmes. As stated in the previous sections, despite the difference in the authors' hierarchy of values, the practice of the states offering compensation programmes has disclosed a number of advantages.

\section{CONCLUSION}

As far as modern liberal societies are concerned, autonomy plays an important role in medicine and public health. Still, the interest of autonomy starts losing its strength when the conduct of a person inflicts harm on other people. When refusing to get vaccinated, a person does damage to others by increasing his/her odds to become infected and transmit the disease to other people (Field \& Caplan; 2008, 16).

Unlike medicine, public health has a long tradition of restraining autonomy for the sake of a public good (Faden et al.; 2003, 1548). When it comes to public policy, it is not which value needs to be respected but how to find the right balance between different values (Field \& Caplan; 2008, 16).

The public good which should be realized by vaccination refers to herd immunity which is expected to prevent circulation of infectious agents within a community. Despite their rareness, adverse events following immunization are rather certain for a small number of people. Due to the circumstance in which a person has suffered damage while enabling realization of a public good, it is not right if he/she carries the burden alone. The traditional 
legal paths to damage compensation have been deemed unsatisfactory. A community must have the duty of damage compensation if it comes to compulsory vaccination or vaccination connected with particular professional obligations (Mello; 2008, 42). In order to overcome the existing problems, states (particularly European ones) are prone to the rising tendency of introducing state-funded compensation programmes. The paper investigates the reasons behind the introduction of these programmes or values which facilitate their implementation. It also tries to indicate the advantages and flaws of these programmes. Our goal was to show the advantages of such programmes for countries like the Republic of Croatia which is currently featured by the state liability for the damage done to an individual but not by a special vaccine injury compensation programme.

\section{REFERENCES}

Asveld, L. (2008) Mass-Vaccination Programmes and the Value of Respect for Autonomy, Bioethics, Vol. 22, No. 5, 245-257, ISSN 0269-9702 (Print), 1467-8519 (Online).

Beauchamp, T. L. \& Childress J. F. (2001) Principles of Biomedical Ethics, 5th edn., Oxford University Press, ISBN 978-0-19-514332-4.

De Castro Lessa, S \& Garoffe Dorea, J. (2013) Bioethics and Mass Childhood Vaccination, Rev. Bioét., Vol. 21, No.2, ISSN 1983-8042 (Print).

Faden, R. R, Taylor H. A., Seiler N. K. (2003) Consent and Compensation: A Social Compact for Smallpox Vaccine Policy in the Event of an Attack, Clinical Infectious Diseases, Vol. 36, No. 12,1547-1551, ISSN 1537-6591.

Field, R. I. \& Caplan, A. L. (2008) A Proposed Ethical Framework for Vaccine Mandates: Competing Values and the Case of HPV, Kennedy Institute of Ethics Journal, Vol. 18, No. 2, 111-124, Print ISSN 10546863, Online ISSN 1086-3249.

Flanigan, J. (2014) A Defence of Compulsory Vaccination, HEC Forum, Vol. 26, No. 1, 5-25, ISSN 0956-2737 (Print) 1572-8498 (Online).

Gilbar, R. \& Bar-Mor, H. (2008) Justice, Equality and Solidarity: The Limits of the Right to Health Care in Israel, Med L Rev, Vol. 16, 225-260, ISSN 0967-0742 (Print) 1464-3790 (Electronic) 0967-0742 (Linking).

Henson, R. (2007-2008) Inoculated against Recovery: A Comparative Analysis of Vaccine Injury Compensation in the United States and Great Britain, Tulsa Journal of Comparative and International Law, Vol. 15, 61-96, ISSN 1073-192X.

Hodge, J. G. \& Gostin, L. O. (2001-2002) School Vaccination Requirements: Historical, Social and Legal Perspectives, Kentucky Law Journal, Vol. 90, 831-890, ISNN 0023-026X (Print).

Looker, C. \& Kelly, H. (2011) No-fault Compensation Following Adverse Events Attributed to Vaccination: A Review of International Programmes, Bulletin of the World Health Organization, 89, 371-378. Retrieved from http://www.who.int/bulletin/volumes/89/5/10-081901/en/ (February 15, 2016).

Malmqvist, E, Helgesson G, Lehtinen J, Natunen K, Lehtinen M. (2011) The Ethics of Implementing Human Papillomavirus Vaccination in Developed Countries, Med Health Care Philos., Vol. 14, No. 1,19-27, ISSN 1386-7423 (Print) 1572-8633 (Online).

Mello, M. M. (2008), Rationalizing Vaccine Injury Compensation, Bioethics, Vol. 22, No. 1, 32-42, ISSN 0269-9702 (Print), 1467-8519 (Online).

Parmet, W. E. (2005) Informed Consent and Public Health: Are They Compatible When it Comes to Vaccines?, Journal of Health Care Law \& Policy, Vol. 8:1, 71-110, Print ISSN 0361-6878 Online ISSN 1527-1927.

Sadurski, W. (2014), Rights Before Courts: A Study of Constitutional Courts in Postcommunist States of Central and Eastern Europe, 2nd ed., Heidelberg [etc.], Springer, ISBN 978-94-017-8934-9.

Shapiro, M. H. (2012) Updating Constitutional Doctrine: An Extended Response to the Critique of Compulsory Vaccination, Yale Journal of Health Policy, Law, and Ethics, Vol. 12, No. 1, 87-170, ISSN 1535-3532.

The February 2004 Decision of the Constitutional Court of the Republic of Slovenia, Decision No. U-I-127/01. Retrieved from http://odlocitve.us-rs.si/documents/12/2c/u-i-127-012.pdf (February 12, 2016).

The June 2007 Decision of the Hungarian Constitutional Court, case No. 39/2007. Retrieved from http://www.mkab.hu/letoltesek/en_0039_2007.pdf (February 12, 2016).

Wilson, K. \& Keelan, J. (2012) The Case for a Vaccine Injury Compensation Program for Canada, Canadian Journal of Public Health, Vol. 103, No. 2, 122-124, ISSN 1920-7476 (Online)

Zagrebelsky, G. (2003), Ronald Dworkin's Principle Based Constitutionalism: An Italian Point of View, Int J Constitutional Law, Vol. 1, No. 4, 621-650, ISSN 1474-2640. 


\section{PRAVNI I ETIČKI TEMELJI ODGOVORNOSTI DRŽAVE ZA NAKNADU ŠTETE NASTALE KAO POSLJEDICE PROVOĐENJA PROGRAMA OBVEZNOG CIJEPLJENJA}

Premda cijepljenje kao suvremenu javnozdravstvenu mjeru od samih početaka njeznog uvođenja prate kontroverze, današnja medicina nema dvojbi u pogledu korisnosti ove mjere za zdravlje pojedinca i cjelokupne zajednice. Cijepljenje je značajno smanjilo pojavu kao i smrtnost od velikog broja zaraznih bolesti. Pri zagovaranju cijepljenja, znanstvenici ističu njegovu djelotvornost $i$ učinkovitost. Vjeruje se da su preventivni nacionalni programi cijepljenja uštedili milijune eura koji bi se potrošili na liječenje i druge medicinske troškove povezane s pojavom bolesti. Cijepljenje kao $i$ ostali lijekovi može proizvesti određene neželjene reakcije. Premda su ozbiljne nuspojave cijepljenja rijetke, u takvim slučajevima naknada štete od velike je važnosti za uspjeh imunizacijskih politika $i$ očuvanja povjerenja javnosti.

Svrha je ovog članka rasvijetliti zašto klasične parnice za naknadu štete nisu u ovom slučaju najbolje rješenje. Oštećenik je često suočen sa potrebom vođenja dugotrajnih sudskih postupaka sa neizvjesnim ishodom.Dojam pojačava činjenica da se takvi sudski postupci često odnose na djecu kojima je potrebna dugotrajna njega. $S$ druge strane, proizvođaći cijepiva također su ranjivi. Proizvodnja cijepiva skupa je i podložna strogom nadzoru. Visoki troškovi parnica za naknadu štete mogu u velikoj mjeri obeshrabriti proizvođaće i navesti ih na prestanak proizvodnje što u konačnici može ugroziti ostvarivanje ciljeva koji se žele postići programima obveznog cijepljenja. Članak nastoji pokazati zašto zemlje, osobito one koje poput Republike Hrvatske obvezuju roditelje na cijepljenje djece protiv određenih zaraznih bolesti trebaju uvesti posebne programe za naknadu štetu koji će ih obvezati da nadoknade štetu pojedincima koji su je pretrpjeli na temelju načela kao što su solidarnost i pravednost.

Ključne riječi: solidarnost, pravednost, jednokost, cijepiva, naknada štete, odgovornost 